\title{
УДК 177:340
}

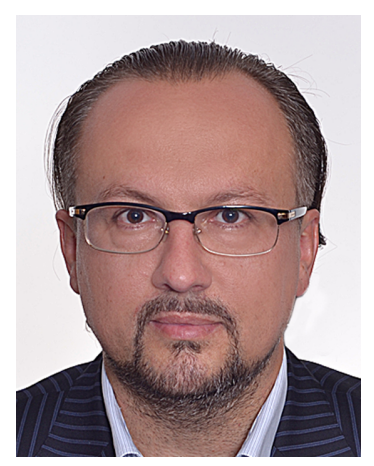

\author{
Несправа М.B. \\ кандидат філософських наук, доцент \\ (Дніпропетровський державний \\ університету внутрішніх справ)
}

\section{МОРАЛЬНІ ОСНОВИ ПРАВА У ФІЛОСОФІЇ ФОМИ АКВІНСЬКОГО}

Проаналізовано погляди Фоми Аквінського на проблему моральної основи права. Показано, що стрижневою чеснотою, котра визначає відносини між людьми, виступає справедливість. Через категорію справедливості охарактеризовано поняття природного і позитивного права. Право визначено як справедливість, якій надано форму закону. Доведено, що закон - це спрямоване на загальне благо і оприлюднене встановлення розуму того, хто покликаний піклуватися про все суспільство. Розкрито походження закону від божественного до природного і далі до людського. Обгрунтовано, що суд є законним в тій мірі, в якій він $є$ актом справедливості.

Ключові слова: справедливість, суспільне благо, право, закон, суд.

Nesprava M.V. Moral basis of law in the philosophy of Thomas Aquinas. Addressing to the Thomas Aquinas's concept of meta-ethics has considerable scientific and practical interest in search the answers to the question of the value dimension of the law in the current Ukrainian state. The purpose of the paper is to show the role of morality as a source of law, the criterion of legality and the basis of order in the state on the basis of the analysis of Aquinas's philosophical heritage. Thomas Aquinas presented the framework of the human soul moral construction, which consists of cardinal virtues. Such cardinal virtue as justice is the carcass design in this framework. The justice directs relations between people exactly, therefore, this virtue acts as a source of law. Summing up Aquinas's thoughts, author defines the law as justice, which is given the form of legality as a general integrity, which concerns not individual preferences, but the welfare of the community as a whole. This conclusion is a cornerstone for defining the principles of law-making in Ukraine. Aquinas first of all pointed out that the law is a rule and a measure of action according to which a person must act or abstain from action. The purpose of the law is public happiness. The general good of the state can't flourish, if its citizens are not virtuous, at least those who are called to manage. Ultimately, Aquinas determined that the law is nothing but a common good and published establishment of the mind of one who is called to take care of the whole society. It is important for the Ukrainian society to establish that the moral virtues of universal justice are the actual criterions for assessing executive agencies, as law application bodies. And any normative act loses the power of the law if it does not serve the interests of the public good. The law makes people good in so far as human actions promote justice. Aquinas was convinced that if one accustoms people to avoid evil and do some good in fear of punishment, then eventually he can come to the point that he will act in such a way with pleasure and his own decision. Therefore, it is very important for Ukrainian law-enforcement officers to

(C) Несправа М.В., 2017 
realize that the law intended to make people good, even by a punishment. The court is legal in so far as it is an act of justice. Aquinas' advices on the personal qualities of judges are also valuable for the implementation of judicial reform in Ukraine. The moral virtues of love, justice and prudence should be placed on the first place when judges evaluated. Thus, having analyzed the philosophical heritage of Thomas Aquinas, author argues that the cardinal moral virtue of justice should be the basis of the activities of the legislative, executive and judicial authorities, and become the basic criterion for assessing the activities of law enforcement bodies for the successful reformation of the legal system of Ukraine.

Key words: justice, public good, law, legality, court.

Постановка проблеми. Українське суспільство переживає складні часи всебічних реформ. У тому числі суттєвій перебудові піддається правова система держави. I, як завжди буває у часи карколомних змін, виникає питання: а які цінності мають бути закладені в основу суспільних, зокрема правових, відносин? Адже громадяни України на власному досвіді переконалися, що без наявності морального стрижня у процесі прийняття і застосування закони можуть бути поставлені не на службу суспільному благу, а на службу корумпованій кліці. Питання моральності права не нове і не $\epsilon$ унікальною українською проблемою. Як зазначає С. І. Максимов, осмислення права в його взаємозв'язку 3 мораллю - одна $з$ найдавніших традицій історії суспільної думки $[1$, с. 179]. Але на кожному новому витку історії ми по-іншому сприймаємо спадщину мислителів минулого, сприймаючи їхні ідеї крізь призму актуальних завдань сьогодення. Ось чому звернення до концепції метаетики одного 3 найвидатніших філософів - Фоми Аквінського - у пошуку відповідей на питання про ціннісний вимір права сучасної Української держави представляє значний науковий і практичний інтерес.

Аналіз публікацій, в яких започатковано розв'язання даної проблеми. Творчий спадок Фоми Аквінського є предметом досліджень багатьох науковців, в першу чергу тих, хто займається історією філософії. Етику Аквіната досліджують, зокрема, такі західні вчені як Р. Ашмор, А. Кенні, С. МакДональд, А. МакІнтайр, Р. МакІнтерні, Дж. Портер, Е. Стамп, Т. Уіл’ямс. Аналіз проблеми людської дії у концепції св. Фоми представлено у працях С. Брока, Т. Гібса, Н. Крецмана, Р. Паснау, С. Свежавскі, Д. Уестберга. Найбільший інтерес 3 точки зору нашого дослідження викликають роботи науковців, які вивчають викладені Аквінським погляди щодо природного і позитивного закону, серед них В. Боурке, М. Мерфі, Дж. Фініс, Ш. Флойд. Глибокий аналіз філософського здобутку Аквінського містися у працях К. В. Бандуровського. Окремі питання вчення Фоми Аквінського є предметом досліджень інших російських вчених. Питання про вічність світу інтерпретує Т. Ю. Бородай. Філософсько-естетичні погляди висвітлює С. А. Дзінкевіч. I тільки В. Гертих певною мірою торкається близької нам проблематики, розглядаючи свободу i моральний закон у Фоми Аквінського (але треба оговоритися, що поняття «моральний закон» у Аквінського немає). Українські вчені також не обходять увагою філософське вчення св. Фоми, хоча більшість 3 них лише згадують окремі положення його теорії у викладенні курсів історії філософії та історії 
держави і права, в енциклопедіях, словниках та ін. Окремі праці, присвячені Аквінському, належать А. Баумейстеру і П. Содоморі. Але вказані академічні розвідки не роблять акценту на тих аспектах, які мають науковий і особливо прикладний інтерес для вирішення правових проблем. Отже, не вирішеною залишається проблема систематизації поглядів Фоми Аквінського на місце i значення моральних принципів у процесі правотворення і правозастосування у контексті завдань українського правознавства.

Мета статті полягає у тому, щоб на основі аналізу філософського спадку Фоми Аквінського показати роль моралі як джерела права, критерію законності та основи правопорядку в державі.

Виклад основного матеріалу. Співвідношення моралі і права є центральнім питанням філософії права. Найглибше цю багатогранну проблему розкрив Фома Аквінський (1225-1274). Для початку філософ показав каркас моральної побудови людської душі, додавши до основних християнських чеснот - віри, надії та любові - ще чотири. Цими чеснотами $є$ розсудливість, справедливість, помірність і мужність [2]. Аквінський ставиться до цих достоїнств як до «кардинальних» чеснот. «Вони є основними звичками, стрижнями, на яких кріпляться інші достоїнства, - вказує Шон Флойд. - При цьому кожна кардинальна чеснота належить до загального типу правоти, який має різні специфікації» [3]. Але несучою конструкцією, стовбуром усієї побудови $\epsilon$ справедливість. «У справедливості $\epsilon$ свій особливий властивий їй об'єкт, якого немає в інших чеснот, і цей об'єкт називається правом, що означає те саме, що і «правота» [2].

Філософія Аквінського дозволяє представити систему права як єдність i взаємозв'язок таких елементів як розум, воля, мораль і правда. На його думку, все, що може бути зроблено правильним за допомогою розуму, $є$ предметом моральної чесноти. Справедливість - це навичка, завдяки якій людина віддає кожному належне, являючи в цьому постійну і нескінченну волю. При цьому під волею мається на увазі не здатність, а акт. Справедливість $є$ те саме, що і правота, але не за своєю суттю, а каузально, оскільки вона є навиком, який робить правим вчинок і волю. Оскільки воля $є$ розумним бажанням, то коли правота розуму, яку називають правдою, відбивається у волі 3 причини ії близькості розуму, цей відбиток зберігає ім'я правди, і тому справедливість іноді називають правдою. Для Аквінського справедливість переважно належить до наших відносин з іншими, і тому він вважає, що «всі чесноти, спрямовані на іншу людину, можуть бути пов'язані з цим загальним аспектом і приєднані до справедливості» [2].

Розкриваючи зміст оцінки соціальних відносин, виходячи 3 критерію справедливості, він вказує, що «правильним», або «правим», $є$ такий вчинок, який узгоджений з іншою людиною за допомогою деякої рівності. Таке уявлення про справедливість може здаватися передвісником більш сучасних дефініцій справедливості, особливо тих, які зображують справедливість 3 точки зору соціальної рівності і економічної солідарності. Але св. Фома дає більш глибоку характеристику і розкриває багатошарову структуру цієї моральної 
категорії. Пояснюючи різницю між природним і позитивним правом, він вказує, що справедливість вчинку може бути погоджена з людиною двояко. За допомогою природного права - це коли людина дає стільки, скільки вона може отримати взамін. I за допомогою позитивного права - це коли щось може бути погоджено або порівняно 3 іншою людиною відповідно до умов деякої спільної згоди, або угоди, за якою сторони, отримуючи стільки-то, вважають себе задоволеними. У свою чергу, позитивне право Аквінський розділяє на два рівні - приватне і суспільне. Перше, котре визначається як особлива справедливість, основане на приватній згоді, яка має бути підтверджена угодою між індивідами. Друге, котре визначається як загальна, або правова справедливість, може бути впроваджене шляхом волі громади або владного встановлення. За першого способу такого впровадження все суспільство погоджується 3 тим, що щось повинно вважатися узгодженим або порівняним з певним суб'єктом. У разі впровадження у другий спосіб цей порядок встановлюється за розпорядженням правителя [4].

I далі, продовжуючи описувати справедливий характер стосунків між людьми, Аквінат спирається на Аристотеля і виділяє два види особливої справедливості - комутативну і дистрибутивну. Обидва ii види прагнуть зберегти рівність між людьми, надаючи кожній людині те, що належне. Проте, Аквінський зазначає, що існують «різні види належного», і цей факт вимагає диференціації справедливості. Комутативна справедливість стосується взаємних відносин між окремими суб'єктами. Зокрема, вона прагне забезпечити, щоб ті, хто купує і продає, чесно вели свій бізнес. У цьому контексті «те, що має бути належним», є свого роду рівністю, за допомогою якої «одна людина повинна повертати іншій тільки стільки, наскільки вона стала багатшою 3 того, що належало іншому». Іншими словами, значення продукту має дорівнювати тому, що людина платить за цей продукт. Так само людині повинна бути виплачена сума, яка дорівнює вартості того, що вона продає [4]. Тобто цей вид справедливості, пов'язаний з рівністю, потребує збереження того, що $є$ питанням кількості.

Дистрибутивна справедливість стосується того, як колективні товари i обов'язки «розподіляються між людьми, які є членами суспільства» [4]. Однак, цей вид справедливості спрямований не на те, щоб люди отримували блага у рівній кількості, але у «належної пропорції». Зрештою, було б несправедливо, якщо «працівникам виплачується рівна заробітна плата за неоднаковий обсяг роботи, або виплачується нерівна заробітна плата за рівний обсяг роботи». Аквінський також вважає, що людині більш високого соціального ступеня потрібна належати більша частка благ. Отже, у питаннях дистрибутивної справедливості «те, що має належати» суб'єкту повинно співвідноситись із тим, що суб'єкт заслуговує залежно від його зусиль або життєвої сили (або потребує, оскільки Аквінський також вважає, що існує моральне зобов'язання забезпечувати бідних) [4].

Очевидно, що зміст аквінатівських дефініцій комутативної та дистрибутивної справедливості виходить далеко за межі теоретичних міркувань і зна- 
ходить своє відображення не тільки у приватних стосунках, але й у цивільному праві держав, які прагнуть розвивати суспільні відносини, зокрема економіку, на ринкових принципах, зберігаючи при цьому принципи соціальної справедливості.

Але досить детально роз'яснюючи зміст особливої справедливості як прикладної, св. Фома розкриває їі діалектичний зв'язок із загальною справедливістю. Він показує як принципи загальної справедливості, спрямовані на благо усієї спільноти, обумовлюють вимоги особливої справедливості, яка направляє нас на благо окремих сусідів, колег та інших людей, з якими ми постійно спілкуємося. Аквінський погоджується, що загальна справедливість може направити нас на благо інших, але тільки побічно [2]. Вона робить це, надаючи нам дуже загальні заповіді (не кради, не вбивай і т. д.), суть яких полягає в тому, щоб допомогти нам своїми діями зберегти загальне благо. I хоча, на думку філософа, ситуації, що вимагають визначення справедливості людських вчинків, принципово не відрізняються, і тому наші міркування про те, що повинно бути правильним, не повинні виходити за рамки того, що диктують ці загальні приписи, проте ми повинні пам'ятати про індивідуальні потреби і діяти розумно при застосуванні цих приписів. Аквінський наполягає на тому, що найбільша турбота про особливу справедливість не може бути загальним благом, але вона служить благу конкретних людей [2]. Таким чином, виконуючи свою мету, особлива справедливість є засобом збереження суспільного добробуту.

В той же час Аквінський наголошує, що саме загальна правова справедливість повинна регулювати всі акти чесноти, щоб гарантувати, що вони досягають своєї мети таким чином, який можна співвіднести з благами інших, бо мета справедливості полягає в тому, щоб керувати нашими діями відповідно до загального блага [4]. Згідно із Аквінським, кожен, хто є членом спільноти, виступає до цього співтовариства як частина цілого. Все, що впливає на частину, також впливає на ціле. Таким чином, все, що добре (або шкідливо) для індивіда, також буде хорошим (або шкідливим) для спільноти, частиною якої він є. 3 цієї причини ми повинні очікувати, що хороше суспільство прийме закони, які регулюватимуть дії його членів у такий спосіб, який буде корисним для усіх. Отже, констатує філософ, цей феномен - добробут громади - $є$ тим, що випливає з правової справедливості. Якщо мета інших чеснот полягає у тому, щоб зробити нас добрими людьми, то мета справедливості зробити нас добрими громадянами [4].

Узагальнюючи думки Аквінського, ми можемо дати таке визначення: право - це справедливість, котрій надано форму закону, це загальна доброчесність, яка стосується не індивідуальних переваг, а добробуту спільноти у цілому.

Розмірковуючи над тим, чим є у цьому контексті закон, філософ перш за усе вказує, що закон є правилом і мірою дій, відповідно до яких людина повинна діяти або утримуватися від дії [5]. Таке визначення у цілому відповідає i сучасній юридичній теорії та практиці. Але цікаво поглянути на точку зору філософа щодо співвідношення інтелектуальної та речової складових закону. 
«Оскільки закон є свого роду правило і міра, він може перебувати в чомунебудь двояко, - пише Аквінат. - По-перше, як в тому, що вимірює і управляє, і якщо бути таким притаманне розуму, то з цього випливає, що саме так закон і знаходиться у розумі. По-друге, як у тому, що вимірюється і управляється. Таким ось чином закон знаходиться в усіх тих речах, які схиляються до чого-небудь за допомогою будь-якого закону, внаслідок чого будь-яка схильність, котра є наслідком закону, може бути названа, якщо так можна висловитися, законом по причетності» [5].

За цією самою логікою св. Фома вказує, що закон має бути опублікованим, бо ті, ким він управляє, повинні знати про керівні настанови. Крім того, письмова фіксація закону надає йому довготривалості та спрямовує у майбутнє. Той, хто не був присутній при оприлюдненні закону, зобов'язаний дотримуватися закону остільки, оскільки він повідомлений або може бути повідомлений про закон іншими після того, як він був оприлюднений [5]. Тобто, хоча закон й міститься у розумі, втім, незнання закону не звільняє від відповідальності.

3 позицій реалій сьогодення, задаючись питанням: у чому полягає мета закону?, вельми корисно прослідувати у пошуку відповіді за логікою Фоми Аквінського. Закон, будучи правилом і мірою людських дій, належить тому, що $\epsilon$ їх початком. Оскільки кінцевою метою дій людини є щастя, а закон спрямовує дій усього суспільства, то він необхідно повинен мати безпосереднє відношення до загального щастя. Отже, правом є тільки те, «що для взаємин у державі створює і зберігає щастя і все, що його складає» [5]. Крім того, якщо закон в першу чергу призначено до загального блага, то всякий інший припис, котрий стосується якої-небудь індивідуальної дії, з необхідністю буде позбавлений природи закону в усьому, що не стосується загального блага [5]. Актуальним звучить і зауваження середньовічного філософа про те, що якщо намір законодавця спрямований не до загального блага, а до того, що доставляє користь або задоволення йому самому чи огидно божественному правосуддю, то в такому випадку закон робить людей добрими не у цілому, а щодо цього конкретного правителя. Крізь призму сучасних подій особливо злободенним здається філософське судження Аквінського про те, що оскільки кожна людина є частиною держави, то неможливо, щоб людина була доброю, якщо іiі благо не є співрозмірним із загальним благом, і точно так само ціле не може бути гармонійним, якщо з ним не співрозмірні його частини [5]. Можна цілковито погодитися із тим, що загальне благо держави не може процвітати, якщо його громадяни не є доброчесними, принаймні, ті 3 них, хто покликаний керувати. Але твердження про те, що для загального блага буде досить і того ступеня доброчинності простих громадян, в силу якого вони коряться розпорядженням своїх правителів, не може бути прийнятним. I це наочно підтвердили події у нашій державі.

У кінцевому рахунку Аквінський визначає, що закон - це спрямоване на загальне благо і оприлюднене встановлення розуму того, хто покликаний піклуватися про все суспільство. І це ми оцінюємо як стовідсоткове попадання у 
те правознавче трактування закону, якого вимагає сучасне суспільство [5].

А зараз ми за допомогою Аквіната розглянемо проблему походження закону. Як видатний теолог, він впевнений, що кожен закон у кінцевому рахунку випливає з того, що він називає вічним законом [6]. «Вічний закон» належить до пророчого упорядкування Богом усіх створених речей до їх належного кінця. Ми беремо участь у цьому божественному порядку в силу того, що Бог створює в нас як бажання, так і здатність розрізняти що є добре i що зле (філософ називає цю здатність «світлом природного розуму»). 3 цієї точки зору природний закон є лише продовженням вічного закону, бо Бог дає нам настанову на остаточне щастя, впроваджуючи в нас як загальне знання, так і схильність до добра. Оприлюднення самого природного закону відбувається за допомогою того, що Бог всіває його в людський розум так, що він стає відомим людині природним чином. Як розуміє Аквінський, природний закон є фундаментальним принципом, який вплетений у тканину нашої природи. Таким чином, він висвітлює і дає нам бажання тих благ, які сприяють процвітанню людини [6]. Відтак, точка зору Аквіната полягає в тому, що ми вчиняємо свої дії заради того, у що ми віримо (правильно чи неправильно) як у добре. Ясно, що багато речей, які ми робимо у житті, не є добрими. Аквінський це не заперечує і погоджується, що пізнавальні помилки та надмірна пристрасть можуть спотворити надані у природному законі моральні настанови i, у свою чергу, схилити нас до вибору неправильних речей. Незважаючи на це, Аквінський не вважає, що наш характер повністю визначає наш вибір, про що свідчить той факт, що ми іноді приймаємо рішення, що суперечать нашим сформованим моральним звичкам як справедливості. Але насправді це є вікном можливостей для нас, оскільки це говорить про те, що навіть люди, схильні до зла, можуть зробити правильний вибір i, можливо, почати виправляти свої більш жорсткі і надмірні схильності. Отже, природний закон не є зовнішнім імперативом. Водночас, це всезагальна деонтична заповідь, з якої виводяться більш конкретні норми позитивного права [6]. Як вказує Аквінат, з приписів природного закону, як із загальних і до того ж неоднозначно трактованих джерел, людський розум повинен приходити до конкретних питань, які належать більш особливим принципам. Ці виведені людським розумом особливі встановлення називаються людськими законами, або позитивним правом [6].

Аквінський наочно демонструє ієрархічний зв'язок природного права 3 позитивним. «Людська воля за спільною згодою може встановлювати в якості законного те, що раніше не розглядалося як таке, але це може мати місце тільки там, де діє не природне, а позитивне право, - пише він. - Однак, якщо щось $є$ противним природному праву, то людська воля не може встановлювати це як законне, наприклад, узаконити крадіжку або перелюб» [4].

Для Аквіната очевидно, що належним наслідком закону є приведення суб'єктів до належної їм чесноти. А якщо призначенням закону є спрямування людських дій до загального щастя, то закон робить людей добрими в тій мірі, в якій людські дії сприяють справедливості. При цьому він виділяє три 
види людських дій. Так, одні дії, а саме добродійні, є по виду благими, і в їх відношенні актом закону є припис, або розпорядження, оскільки «закон наказує всі справи справедливості». Інші дії, а саме порочні, є по виду злими, і в їх відношенні актом закону є заборона. Деякі дії, які не є ні очевидно благими, ні очевидно дурними, байдужі за своїм виглядом, і в їх відношенні актом закону є дозвіл [7].

На окрему увагу заслуговує думка Аквінського щодо каральної функції закону. Богослов не закликає тільки до порад і заохочення. Радити властиво не стільки закону, скільки приватній особі, яка не може встановлювати закон. Винагороджувати має право кожен, а карати - ніхто, крім представника закону, який наділений повноваженням завдавати страждань. Страх перед покаранням закон використовує з тим, щоб забезпечити покору закону, яке у сенсі покарання також є наслідком закону. Аквінський - реаліст і вбачає, що покора закону не завжди обумовлюється досконалістю чесноти, часом вона пов'язана зі страхом перед покаранням або просто приписом розуму, але це, як було показано вище, вже є зародком чесноти. Аквінський впевнений, що якщо привчити людину уникати зла і робити добро через страх перед покаранням, то з часом вона може прийти до того, що стане діяти таким чином із задоволенням і за власним рішенням [7]. Отже, для правоохоронців дуже важливо усвідомлювати, що закон навіть за посередництвом покарання здатен робити людей добрими.

Але навіть за наявності закону справедливість не може бути встановлена без суду. Сучасна правозастосовна практика впевнено підтверджує важливість судової гілки влади у впровадженні цієї моральної чесноти у суспільстві. Реформування судової системи неможливе без розуміння того, що «суд $є$ актом справедливості в тій мірі, в якій справедливість схиляє судити до винесення правого судження». I це моральне судження до нас доходить зі спадщини Аквінського. За цим логічно слідують і практичні висновки вченого. Суд є законним в тій мірі, в якій він є актом справедливості. Для того, щоб акт був справедливим, необхідно дотримання трьох умов: по-перше, щоб він відбувався з прихильності до справедливості; по-друге, щоб він виходив від того, хто наділений відповідними повноваженнями; по-третє, щоб його оголошення було правильно спрямовано розважливістю. Якщо ж що-небудь 3 цього відсутнє, то суд є неякісним і незаконним, а саме: по-перше, коли він огидний правоті справедливості, і тоді його називають «збоченим» або «неправедним»; по-друге, коли людина судить про те, про що судити не має права, i такий суд називають «неправомочним»; по-третє, коли розуму бракує впевненості, як коли хто-небудь судить про щось неочевидно, недостовірно i без серйозних на те підстав, і такий суд називають судом «сумнівним» або «поспішним» [8].

Неабияку цінність мають і поради Аквіната щодо персональних якостей суддів. На перше місце він ставить моральні чесноти любові, справедливості та розсудливості. Духовна людина, володіючи навичкою до любові, схильна правильно судити про все відповідно до божественного права, що узгоджу- 
ється 3 винесенням судження за посередництвом дару мудрості. Це подібно до того, як справедлива людина виносить судження за посередництвом чесноти розсудливості, яка узгоджена з постановою закону [8].

Висновки. Фома Аквінський представив каркас моральної побудови людської душі, який складається 3 кардинальних чеснот. Несучою конструкцією у цьому каркасі виступає така кардинальна чеснота як справедливість. Саме справедливість спрямовує відносини між людьми. Відтак, ця чеснота виступає як джерело права. Даючи глибоку характеристику і розкриваючи багатошарову структуру цієї моральної категорії, Аквінський показує різницю між природним і позитивним правом, а також визначає такі види справедливості як комутативна і дистрибутивна. Диференціюючи справедливість на особливу і загальну, він аргументує діалектику їхнього взаємозв'язку та доводить пріоритетність загальної справедливості у суспільному житті. Загальна справедливість виступає як правова. Добробут громади є тим, що випливає саме $з$ правової справедливості. Узагальнюючи думки Аквінського, ми визначаємо право як справедливість, котрій надано форму закону, як загальну доброчесність, котра стосується не індивідуальних переваг, а добробуту спільноти у цілому. Цей висновок є наріжним каменем для визначення принципів правотворення в Україні.

Щодо застосування норм закону у суспільному житті, то треба звернути увагу на таке. Аквінський перш за усе вказує, що закон є правилом і мірою дій, відповідно до яких людина повинна діяти або утримуватися від дії. Метою закону є суспільне щастя. Тому всякий інший припис, котрий стосується якої-небудь індивідуальної дії, з необхідністю буде позбавлений природи закону в усьому, що не стосується загального блага. Загальне благо держави не може процвітати, якщо його громадяни є недоброчесними, принаймні, ті 3 них, хто покликаний керувати. У кінцевому рахунку Аквінський визначає, що закон - це спрямоване на загальне благо і оприлюднене встановлення розуму того, хто покликаний піклуватися про все суспільство. Для українського суспільства важливо встановити, що актуальним критерієм оцінки установ виконавчої влади, як органів правозастосування, є моральні чесноти загальної справедливості. А будь-який нормативний акт втрачає силу правочину, якщо він не служить інтересам суспільного блага.

Для Аквіната очевидно, що належним наслідком закону є приведення суб'єктів до належної їм чесноти. А якщо призначенням закону є спрямування людських дій до загального щастя, то закон робить людей добрими в тій мірі, в якій людські дії сприяють справедливості. Аквінський впевнений, що якщо привчити людину уникати зла і робити добро через страх перед покаранням, то з часом вона може прийти до того, що стане діяти таким чином із задоволенням і за власним рішенням. Відтак, для українських правоохоронців дуже важливо усвідомлювати, що закон навіть за посередництвом покарання покликаний робити людей добрими.

Але навіть за наявності закону справедливість не може бути встановлена без суду. Суд є законним в тій мірі, в якій він є актом справедливості. Для то- 
го, щоб судовий акт був справедливим, необхідно дотримання трьох умов: поперше, щоб він відбувався з прихильності до справедливості; по-друге, щоб він виходив від того, хто наділений відповідними повноваженнями; по-третє, щоб його оголошення було правильно спрямовано розважливістю. Неабияку цінність для реалізації судової реформи в Україні мають і поради Аквіната щодо персональних якостей суддів. При їх оцінці на перше місце мають бути поставлені моральні чесноти любові, справедливості та розсудливості.

Таким чином, проаналізувавши філософську спадщину Фоми Аквінського, ми можемо констатувати, що для успішного реформування правової системи України кардинальна моральна чеснота справедливості має бути покладена в основу діяльності органів законодавчої, виконавчої та судової влади, а також стати базовим критерієм для оцінки діяльності правоохоронних органів.

Перспективи подальших розвідок у цьому напрямку полягають у напрацюванні більш конкретних пропозицій щодо імплементації філософських сентенцій у правову систему України.

\section{Бібліографічні посилання}

1. Максимов С. І. Універсальне і культурно-особливе у ціннісному вимірі права / C. I. Максимов // Філософія права : підруч. для студ. юрид. вищ. навч. закл. / О. Г. Данильян, О. П. Дзьобань, С. І. Максимов та ін. / за ред. д-ра філос. наук, проф. О. Г. Данильяна. - Х. : Право, 2009. - 208 с.

2. Аквинский Ф. О справедливости, вопрос 58 / Фома Аквинский / Сумма теологии. Том VIII. / С. И. Еремеев: перевод, редакция, примечания. - К. : Ника-Центр, 2010. - 432 с. [Электронный ресурс].- Режим доступа: https://azbyka.ru/otechnik/konfessii/summa-teologiitom-8/12.

3. Floyd S. Thomas Aquinas: Moral Philosophy / Shawn Floyd // The Internet Encyclopedia of Philosophy (IEP) [Online]. - Access: http://www.iep.utm.edu/aq-moral/ (Date of access 03.11.2017).

4. Аквинский Ф. О праве, вопрос 57 / Фома Аквинский / Сумма теологии. Том VIII. / С. И. Еремеев: перевод, редакция, примечания. - К. : Ника-Центр, 2010. - 432 с. [Электронный ресурс]. - Режим доступа: https://azbyka.ru/otechnik/konfessii/summa-teologii-tom$8 / 11$.

5. Аквинский Ф. О сущности закона, вопрос 90 / Фома Аквинский / Сумма теологии. Том VI. / С. И. Еремеев: перевод, редакция, примечания. - К. : Ника-Центр, 2010. - 432 с. [Электронный pecypc]. - Режим доступа: https://azbyka.ru/otechnik/konfessii/summateologii-tom-6/1_1.

6. Аквинский Ф. О различных видах закона, вопрос 91 / Фома Аквинский / Сумма теологии. Том VI. / С. И. Еремеев: перевод, редакция, примечания. - К. : Ника-Центр, 2010. - 432 с. [Электронный pecypc]. - Режим доступа: https://azbyka.ru/otechnik/konfessii/summa-teologii-tom-6/2.

7. Аквинский Ф. О следствиях закона, вопрос 92 / Фома Аквинский / Сумма теологии. Том VI. / С. И. Еремеев: перевод, редакция, примечания. - К. : Ника-Центр, 2010. 432 с. [Электронный ресурс]. - Режим доступа: https://azbyka.ru/otechnik/konfessii/summateologii-tom-6/3.

8. Аквинский Ф. О суде, вопрос 60 / Фома Аквинский / Сумма теологии. Том VIII. / С. И. Еремеев: перевод, редакция, примечания. - К. : Ника-Центр, 2010. - 432 с. [Электронный ресурс]. - Режим доступа: https://azbyka.ru/otechnik/konfessii/summa-teologii-tom8/14_1. 